Check for updates

\section{London}

Cite this as: BMJ2020;369:m2477 http://dx.doi.org/10.1136/bmj.m2477 Published: 19 June 2020

\title{
Covid-19: Health and care workers will be "highest priority" for vaccination, says JCVI
}

Jacqui Wise

"Frontline" health and social care workers will be the "highest priority for vaccination" once a vaccine against covid-19 becomes available, the UK Joint Committee on Vaccination and Immunisation has said.

The next priority group for vaccination should be people at increased risk of serious disease and death from covid-19 infection according to age and risk factors such as underlying health conditions, says preliminary advice from the JCVI. ${ }^{1}$ It said work was continuing to identify which groups were most at risk and noted that "early signals have been identified of other potential risk factors including deprivation and ethnicity."

The advice was developed in response to a request by the Department of Health and Social Care for England and Public Health England. Speaking at the daily government press briefing on Thursday 18 June, the health and social secretary, Matt Hancock, said, "As we learn more about the virus we will continue to take into account which groups may be particularly vulnerable, including for example those from ethnic minority backgrounds."

The JCVI said that frontline health and social care workers were at increased personal risk of exposure to infection with covid-19 and of transmitting that infection to susceptible and vulnerable patients. Vaccinating this group would also help to maintain resilience in the NHS and among health and social care providers, the committee said.

The advice says that people at greatest risk of severe illness and mortality from covid-19 include adults over the age of 50 (with the risk increasing with age) and those with underlying comorbidities such as chronic heart disease, chronic kidney disease, chronic pulmonary disease, malignancy, obesity, and dementia. Also considered to be at greatest risk is the current shielded population, which includes people who have undergone solid organ transplantations, those with severe respiratory conditions, including cystic fibrosis, and those on immunosuppression therapies.

However, the committee said that work continued to more clearly define who was at greatest risk and said the list would be updated as "more information and granular data become available.”

Several vaccines for covid-19 are currently being developed and tested around the world. ${ }^{2}$ One being developed by Imperial College London is in the first phase of human clinical trials, and the drug company AstraZeneca has struck a deal for the manufacture of a vaccine being developed by Oxford University. Hancock said at the briefing, “They're starting manufacturing now, even ahead of approval, so we can build up a stockpile and be ready, should it be clinically approved.”

The JVCI said there were important gaps in the current understanding of covid-19 concerning natural immunity, transmission dynamics, and the role of ethnicity and sex. It is not known whether a safe and effective vaccine can be developed and, if it did become available, for which age groups it would be licensed, how effective it would be across different age groups, and how long protection would last.

1 Joint Committee on Vaccination and Immunisation. Interim advice on priority groups for covid-19 vaccination. Jun 2020. https://www.gov.uk/government/publications/priority-groups-for-coronavirus-covid-19-vaccinationadvice-from-the-jcvi/interim-advice-on-priority-groups-for-covid-19-vaccination.

2 Mahase E. Covid-19: What do we know so far about a vaccine?BMJ 2020;369:m1679. doi: 10.1136/bmj.m1679 pmid: 32340998

This article is made freely available for use in accordance with BMJ's website terms and conditions for the duration of the covid-19 pandemic or until otherwise determined by BMJ. You may use, download and print the article for any lawful, non-commercial purpose (including text and data mining) provided that all copyright notices and trade marks are retained. 